\title{
The Effect of Environmental Factors on the Herbicidal Activity of Pyrazosulfuron-ethyl under Paddy Conditions*
}

\author{
Koichi Suzuki**, Tsutomu Nawamaki** and Shigeomi Watanabe**
}

\begin{abstract}
The effect of environmental factors on the herbicidal activity of pyrazosulfuron-ethyl was examined by pot tests in a greenhouse. Uptake site of pyrazosulfuron-ethyl in Cyperus serotinus Rottb. was determined by two application methods, i.e., surface water application for shoot uptake and soil incorporation for root uptake. Pyrazosulfuron-ethyl significantly reduced the growth with soil incorporation, while no reduction was observed with surface water application. Leaching and shallow planting depth, which increase the root uptake of pyrazosulfuron-ethyl in $C$. serotinus, enhanced the activity. Lower temperature conditions $\left(20 / 15^{\circ} \mathrm{C}\right)$ resulted in higher activity than did higher temperature $\left(25 / 20,30 / 25^{\circ} \mathrm{C}\right)$.
\end{abstract}

Soil relations were examined using 15 paddy soils in Japan. Pyrazosulfuron-ethyl adsorption to soil was significantly related to soil $\mathrm{pH}$. However, no relationship was observed between soil adsorption and effectiveness against Echinochloa oryzicola Vasing.. Higher activity of pyrazosulfuron-ethyl tended to be found in soils containing less organic matter.

Key words : pyrazosulfuron-ethyl, environmental factors, uptake site, Cyperus serotinus

\footnotetext{
* A part of this paper was presented at the annual meeting of the Weed Science Society Japan in 1988.

** Shiraoka Research Station of. Biological Science, Nissan Chemical Industries, Ltd., 1470 Shiraoka, Saitama, Japan.

(Received August 17, 1993)
}

\section{Introduction}

Pyrazosulfuron-ethyl, Ethyl 5- (4, 6-dimethoxypyrimidin-2-ylcarbamoylsulfamoyl)-1-methylpyrazole-4-carboxylate, is a sulfonylurea herbicide for paddy rice and for turf, having been discovered and developed by Nissan Chemical Industries, Ltd. It has a wide weed control range including perennial broadleaf weeds and Cyperacae weeds at the rate of $0.2-0.3 \mathrm{~g}$ a.i./a. ${ }^{9}$. Pyrazosulfuron-ethyl is commercially used singly or combined with grass herbicides in several rice producing countries.

Performance of paddy herbicides is usually affected by environmental factors including soil properties, temperature, water leaching, water management and so on ${ }^{3,4,6,8}$.

In this paper, the authors present the effect of environmental factors on the activity of pyrazosulfuron-ethyl under paddy conditions.

\section{Materials and Methos}

\section{Uptake site of pyrazosulfuron-ethyl in Cyper- us serotinus Rottb.}

Two application methods were used to estimate the uptake site of the compound in Cyperus serotinus Rottb. i.e. soil incorporation for root uptake and surface water application for shoot uptake. A suspension of wettable powder was applied and incorporated in a root zone $2 \mathrm{~cm}$ in thickness just before planting or was applied to surface water just after planting (Fig. 1). Germinated tubers were planted at 2 per pot at a depth of $2 \mathrm{~cm}$. 


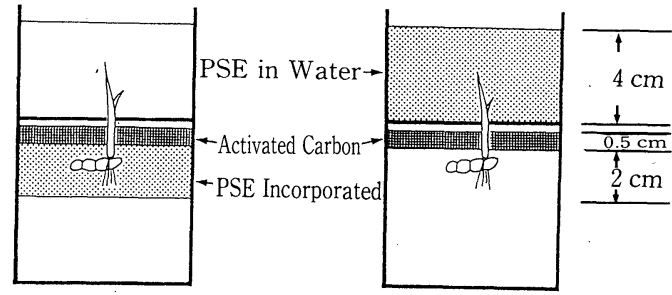

Fig. 1. Methods Used to Apply Pyrazosul furonethyl (PSE).

Surface water was kept at a $4 \mathrm{~cm}$ depth and plants were grown in a greenhouse. Shoot fresh weight was measured 21 days after application. These tests were conducted with three replications.

\section{Factors affecting the herbicidal activity of pyrazosulfuron-ethyl}

One and one half liter plastic pots with a 100 $\mathrm{cm}^{2}$ surface area were used for the trials. Pots were filled with paddy sub-soil (clay loam soil, clay $26.4 \%$, silt $40.2 \%$, sand $33.4 \%$, total-carbon $2.3 \%, \mathrm{pH} 6.0$ ), and then the soil was mixed with water and 3 grams of compound fertilizer (15-15$\left.10: \mathrm{N}, \mathrm{P}_{2} \mathrm{O}_{5}, \mathrm{~K}_{2} \mathrm{O}\right)$. Germinated tubers of Cyperus serotinus Rottb. were planted $1 \mathrm{~cm}$ in depth at two per pot and were grown in a greenhouse. Water depth was kept at $4 \mathrm{~cm}$ and no leaching was done during the test period. Three to seven days after planting, when plant height was from 5 to $15 \mathrm{~cm}$, a wettable powder suspension of pyrazosulfuron-ethyl was applied to the surface water. Visual assessments were made at appropriate intervals after application; fresh weight of plant shoots was measured 20 to 24 days after. a) Effect of water depth: Just prior to application, surface water depth was adjusted to 1,4 or $8 \mathrm{~cm}$.

b) Effect of leaching: Suspension of pyrazosulfuron-ethyl was applied to surface water $4 \mathrm{~cm}$ in depth, leaching at 0 or $2 \mathrm{~cm}$ per day was done for three days from the day following application. c) Effect of tuber depth: Tuber were planted 0,1 , and $3 \mathrm{~cm}$ below soil surface. d)
Effect of temperature: After application, pots were moved to growth chambers where temperature was controlled at $30 / 25^{\circ} \mathrm{C}$ (day/night), 25/ $20^{\circ} \mathrm{C}$ or $20 / 15^{\circ} \mathrm{C}$.

All tests were conducted with three replications.

\section{Herbicidal activity of pyrazosulfuron-ethyl in different types of soil}

Paddy soil collected from 15 locations including prefectural agricultural stations in Japan was used for this test. Soil was air-dryed and put through a $2 \mathrm{~mm}$ sieve. A plastic beaker with a volume of $200 \mathrm{ml}$ was filled with 150 grams of test soil. Then soil was mixed with fertilizer and water for paddy conditions. Echinochloa oryzicola Vasing. was seeded in a pot, followed by application of a wettable powder suspension of pyrazosulfuron-ethyl the same day. Plants were then grown in a greenhouse for eighteen days, and the fresh weight was measured. Tests were conducted with three replications.

\section{Soil adsorption in different soil types}

Fifteen different types of soil shown in Table 1 were used for the adsorption test. The method was based on that of Hirai and Kawamura ${ }^{2}$. Two hundred ten grams air dried soil was put in a one liter Erlenmeyer flask, then $420 \mathrm{ml}$ of distilled water containing pyrazosulfuron-ethyl at 42 ppb was added. Flasks closed with rubber stoppers were shaken for two hours at $25^{\circ} \mathrm{C}$ in a water bath. One hour later, supernatant was centrifuged for fifteen minutes at 4,000 rpm. One hundred $\mathrm{ml}$ of supernatant was extracted with benzene twice and was cleaned up by SEP-PACK column. The extract was evaporated under a nitrogen gas stream, then was resolved with dichloromethane and pyrazosulfuron-ethyl was determined by a high performance liquid chromatograph (HPLC) (Hitachi L-6000, column: Nucleosil 50-5 $25 \mathrm{~cm} \times 4.6 \mathrm{~mm}$ in diameter, eluent : n-hexane/ethyl acetate/acetic acid $=65 / 35 / 2$, flow rate : $1 \mathrm{ml} / \mathrm{min}$., detector : UV detector at $254 \mathrm{~nm}$ ). 
Table 1. Soil properties, soil adsorption of PSE and herbicidal activity in each soil.

\begin{tabular}{|c|c|c|c|c|c|c|c|}
\hline \multirow[b]{2}{*}{ Location } & \multicolumn{3}{|c|}{ Physical Component } & \multirow{2}{*}{$\begin{array}{c}\text { Total } \\
\text { Carbon } \\
(\%)\end{array}$} & \multirow{2}{*}{$\begin{array}{c}\text { Soil } \\
\mathrm{pH} \\
\left(\mathrm{H}_{2} \mathrm{O}\right)\end{array}$} & \multirow{2}{*}{$\begin{array}{l}\text { PSE Con- } \\
\text { centration } \\
\text { in Water }\end{array}$} & \multirow{2}{*}{$\begin{array}{c}\text { ECHOR } \\
I_{75} \\
(\mathrm{mg} / \mathrm{a})\end{array}$} \\
\hline & $\begin{array}{c}\text { Sand } \\
(\%)\end{array}$ & $\begin{array}{l}\text { Silt } \\
(\%)\end{array}$ & $\begin{array}{c}\text { Clay } \\
(\%)\end{array}$ & & & & \\
\hline Hokkaido Chuou Agr. Stn. & 8.0 & 37.8 & 54.2 & 4.6 & 5.3 & 11.6 & 84 \\
\hline Furukawa Agr. Stn. & 17.4 & 52.6 & 30.0 & 2.7 & 5.2 & 12.9 & 60 \\
\hline Aizu Branch Stn. & 43.8 & 32.4 & 23.8 & 3.3 & 6.3 & 33.1 & 86 \\
\hline Niigata Agr. Stn. & 36.1 & 32.6 & 31.3 & 1.7 & 5.6 & 9.8 & 64 \\
\hline Tochigi Agr. Stn. & 53.2 & 39.6 & 7.3 & 8.6 & 6.5 & 27.4 & 89 \\
\hline Gunma Agr. Stn. & 63.6 & 31.1 & 5.3 & 2.3 & 4.9 & 26.1 & 20 \\
\hline Saitama Agr. Stn. & 49.9 & 27.3 & 22.8 & 1.7 & 5.9 & 34.8 & 68 \\
\hline Hasuda, Saitama & 82.8 & 9.2 & 8.0 & 0.70 & 4.8 & 11.4 & 48 \\
\hline Shiraoka, Saitama & 18.5 & 35.1 & 46.4 & 4.2 & 5.3 & 11.6 & 46 \\
\hline Shiraoka Sub-soil & 33.4 & 40.2 & 26.4 & 2.3 & 6.0 & 31.4 & 28 \\
\hline Osaka Agr. Center & 58.8 & 26.4 & 14.8 & 1.8 & 7.1 & 39.3 & 60 \\
\hline Hyougo Agr. Center & 55.3 & 29.8 & 14.9 & 1.6 & 5.5 & 14.2 & 48 \\
\hline Okayama Agr. Stn. & 61.9 & 21.4 & 16.7 & 1.6 & 6.4 & 39.4 & 26 \\
\hline Kagawa Agr. Stn. & 62.9 & 23.8 & 13.3 & 1.0 & 5.8 & 32.7 & 42 \\
\hline Kagoshima, Kagoshima & 64.0 & 23.9 & 12.1 & 1.9 & 4.9 & 25.2 & 31 \\
\hline
\end{tabular}

\section{Results and Discussion}

\section{Uptake Site of Pyrazosulfuron-ethyl in Cyperus serotinus Rottb.}

As described, pyrazosulfuron-ethyl was applied to surface water or to the root zone of $C$. serotinus in a pot. Surface water application resulted in little activity against $C$. serotinus, while root zone application caused significant reduction of growth at the same rate (Fig. 2). A similar tendency was

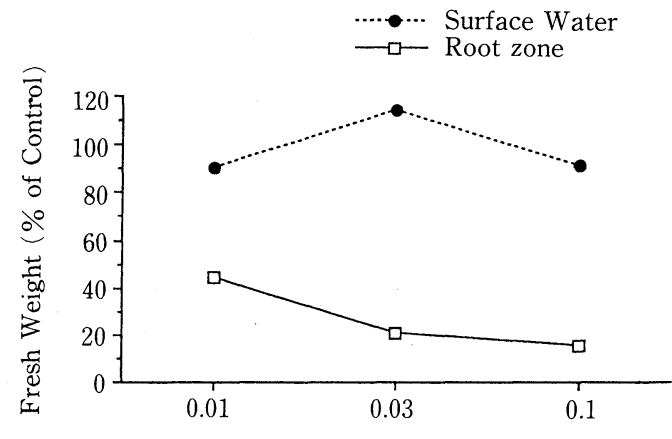

Application Rates (g/a)

Fig. 2. Uptake site of PSE with Cyperus serotinus Rottb. (CYPSE).

Fresh weight 21 days after treatment. observed with transplanted rice (data not shown). From these results, pyrazosulfuron-ethyl is believed to be mainly absorbed by the plant roots.

Factors affecting the herbicidal activity of pyrazosulfuron-ethyl under paddy conditions

The effect of water depth was evaluated with pot tests in a greenhouse. Although deeper water conditions tended to slightly increase efficacy, the difference was minimal (Fig. 3). A similar tendency was reported with butachlor ${ }^{3}$

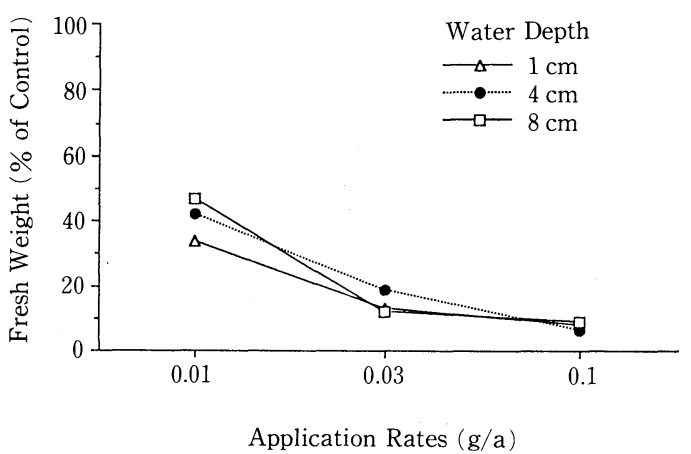

Fig. 3. Effect of water depth on herbicidal activity of PSE.

Fresh weight of CYPSE 20 days after treatment. 


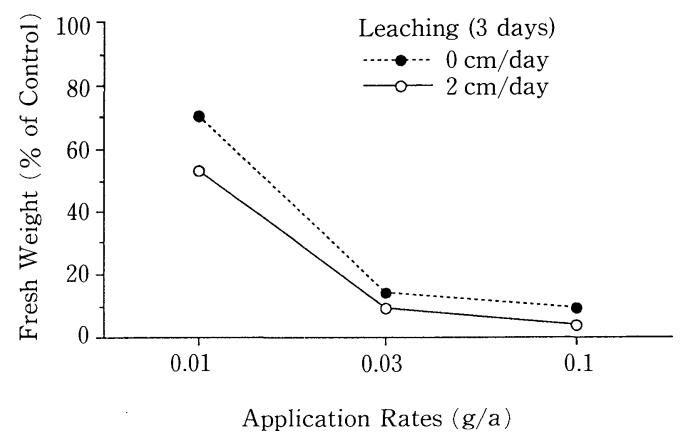

Fig. 4. Effect of leaching on herbicidal activity of PSE.

Fresh weight of CYPSE 21 days after treatment.

and pretilachlor ${ }^{6)}$ under paddy conditions.

Leaching operation at $2 \mathrm{~cm} /$ day for three days increased the efficacy of pyrazosulfuron-ethyl compared with the conditions without leaching (Fig. 4); however, the difference was less than that expected from the results of the uptake site. As tuber were planted at a depth of only $1 \mathrm{~cm}$ in this test, rooting of $C$. serotinus was thought to occur in a shallow position beneath the soil surface. Under these conditions some amount of diffused pyrazosulfuron-ethyl is thought to be absorbed through the root system unless leaching is not done.

Planting depth of tubers affected the activity against $C$. serotinus, i.e., those planted $0 \mathrm{~cm}$ deep experienced the highest suppression and inhibition of those planted at $3 \mathrm{~cm}$ was the least (Fig. 5).

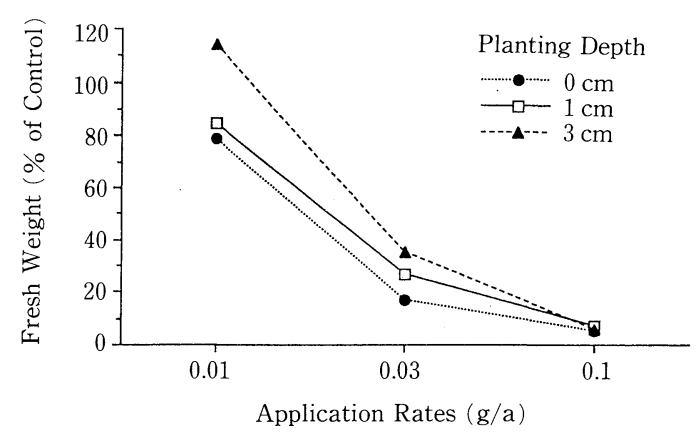

Fig. 5. Effect of tuber planting depth on herbicidal activity.

Fresh weight 24 days after treatment.

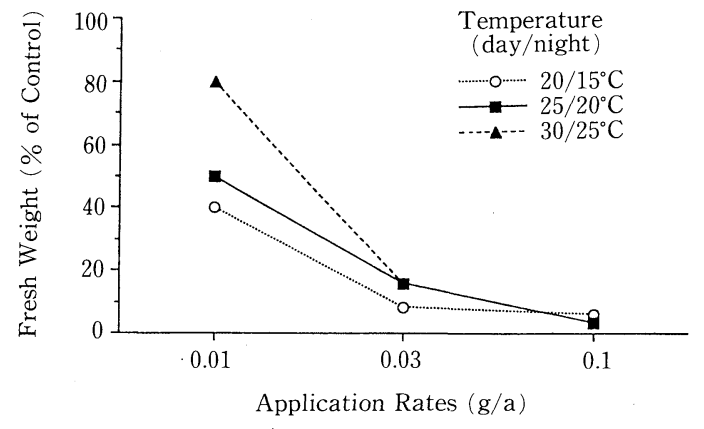

Fig. 6. Effect of temperature on herbicidal activity. Fresh weight of CYPSE 18 days after treatment.

The difference in planting depth was also less than expected, probably for the same reason as mentioned above.

Plants were subjected to different temperature conditions ranging from $20 / 15^{\circ} \mathrm{C}$ (day/night) to $30 / 25^{\circ} \mathrm{C}$ after application of the herbicide. Under the lowest temperature, pyrazosulfuron-ethyl demonstrated the highest activity against $C$. serotinus, while under the highest temperature, the activity was the lowest (Fig. 6). Similar tendency was observed with phytotoxicity of transplanted rice (data not shown). Many paddy herbicides are known to increase the activity under higher temperature conditions; for example, it was reported that the control of E. oryzicola with butachlor, PCP or chloronitrofen decreased under lower temperature conditions ${ }^{3,7)}$. The temperature response of pyrazosulfuron-ethyl was the opposite of these paddy herbicides. The similar characteristics of paddy herbicides were reported for cinmethylin ${ }^{5}$.

\section{Herbicidal activity of pyrazosulfuron-ethyl in various soil.}

$\mathrm{I}_{75}$ values against barnyardgrass in each soil varied from $26 \mathrm{mg} / \mathrm{a}$ to $89 \mathrm{mg} / \mathrm{a}$ (Table 1 ). The correlations between $\mathrm{I}_{75}$ values and soil properties were examined, but no significant relation was observed with clay content or $\mathrm{pH}$ (Table 2). A slight correlation was found with carbon content in the soil, and the activity of pyrazosulfuron- 
Table 2. Correlations between soil properties and herbicidal activity/PSE concentration in water.

\begin{tabular}{lllll}
\hline Clay\% & - & $\mathrm{I}_{75}$ & $\mathrm{Y}=41.8+0.529 X$ & $\mathrm{r}=0.336$ \\
Carbon\% & - & $\mathrm{I}_{75}$ & $\mathrm{Y}=35.9+6.53 \mathrm{X}$ & $\mathrm{r}=0.576$ \\
$\mathrm{pH}$ & - & $\mathrm{I}_{75}$ & $\mathrm{Y}=-9.28+11.0 \mathrm{X}$ & $\mathrm{r}=0.332$ \\
Clay\% & - PSE Conc. & $\mathrm{Y}=31.72-0.351 \mathrm{X}$ & $\mathrm{r}=0.449$ \\
Carbon\% & - PSE Conc. & $\mathrm{Y}=25.4-0.508 \mathrm{X}$ & $\mathrm{r}=0.009$ \\
$\mathrm{pH}$ & - PSE Conc. & $\mathrm{Y}=-42.2+11.62 \mathrm{X}$ & $\mathrm{r}=0.705$ \\
PSE Conc. & - & $\mathrm{I}_{75}$ & $\mathrm{Y}=60.7-0.305 X$ & $\mathrm{r}=0.152$ \\
\hline
\end{tabular}

ethyl tended to be higher in soil containing less total carbon. Herbicidal activity of oxadiazon was reportedly correlated with CEC and organic matter content with the exception of black volcanic ash soil ${ }^{21}$; this was also true of naproanilide ${ }^{8)}$. A comparison of these herbicides did not reveal any major soil factors affecting the activity.

\section{Soil adsorption in different soils}

Soil adsorption of pyrazosulfuron-ethyl was highest in Niigata and lowest in Okayama soil (Table 1). No significant relation was observed with clay content or total carbon, however, soil $\mathrm{pH}$ was significantly related with the soil adsorption (Table 2). Pyrazosulfuron-ethyl is a weak acid as other sulfonylurea herbicides, having a pKa value of 3.7 , and its water solubility depends on $\mathrm{pH}$. The results of the soil adsorption were considered due to the characteristics of the sulfonylurea molecule ${ }^{1}$. Although the reason of no correlation between herbicidal activity and adsorption is still under investigation, many factors such as degradation of the compound, the ratio of neutral/acid form and change of soil $\mathrm{pH}$ are believed to be complexed.

\section{References}

1) Brown, H.M. 1990. Mode of action, crop selectivity, and soil relations of the sulfonylurea herbicides. Pestic. Sci. 29, 263-281.

2) Hirai, K., Y. Kawamura 1975. Studies on a new herbicide, oxadiazon IV. influence of soil properties on the herbicidal activity of oxadiazon under flooded conditions of paddy fleld. Weed Res., Japan 20(2), 61-66.

3) Ichizen, N., T. Takeuchi, H. Omokawa, M. Konnai and T. Takematu 1991. Effect of soil type, water depth, water leakage and temperature on activity of flowable and granular formulations of herbicides. Weed Res., Japan 36(4), 338-342.

4) Ichizen, N., K. Yoneyama, M. Konnai and T. Takematu 1991. Effect of overflow caused by rain on efficacy of flowable and granular formulations against Echinochloa oryzicola. Weed Res., Japan 36(4), 334-337.

5) Jones, R.C., T. Iinuma and M.W. Murphy 1987. WL95481-a novel herbicide for use in flooded, transplanted rice. Proceeding of the 11th Asian Pacific Weed Science Society, 407-413.

6) Murakami, S. 1990. Glasshouse study on herbicidal activity of pretilachlor on rice and Echinochloa oryzicola Vasing. Weed Res., Japan 35(2), 155-163.

7) Noda, K., K. Ibaraki and K. Ozawa 1965. Variation in activity of herbicides as influenced by air temperature. Weed Res., Japan 4, 127-131.

8) Tanaka, T. and M. Oyamada 1991. Effect of paddy soil properties on herbicidal activity of naproanilide. Weed Res., Japan 36(2), 171-175.

9) Yamamoto, S., T. Sato, Y. Iwasawa, F. Suzuki, T. Ikai, K. Suzuki and T. Nawamaki 1990. Selective herbicidal activities of ethyl 5-(4, 6dimethoxypyrimidin-2-ylcarbamoylsulfamoyl)1-methylpyrazole-4-carboxylate and its related compounds. J. Pesti Sci., 15(4), 531538 . 
水田条件における各種環境要因がピラゾスルフ ロンエチルの除草効果に与える影響

鈴木宏一*・繩巻 勤*・渡辺重臣*

\section{摘要}

水田条件における各種環境要因がピラゾスルフロ ンエチル（PSE）の除草効果に与える影響を，温室 内のポット試験で検討した。

1) ミズガヤツリ（Cyperus serotinus Rottb.）を 用いてPSEの植物における吸収部位の推定を行っ た。PSEの拡散を活性炭層で防いだ条件で，湛水中 あるいは地下部にPSE を処理した結果, 湛水中処理 では殆ど活性を示さなかったのに対して，土壤中に 混和処理した場合に, 顕著な除草活性を示した。従つ て, PSE の植物体における主な吸収部位は地下部に

*日産化学工業 (侏) 生物科学研究所
あると考えられた。

2) 湛水深, 減水深, 発生深度, 温度の各条件につ いて,これらの変動が PSE の除草効果に与える影響 をミズガヤツリを用いて検討した。地下部からの PSE の吸収を助長する条件, つまり適度な減水深を 与えた場合，あるいは，発生深度の浅い場合に除草 効果は向上した。温度条件では，むしろ低温下 $(20$ \% $\left.15^{\circ} \mathrm{C}\right)$ で除草効果が高い傾向がみられた。

3） 15 種の水田土壤を用いて, PSEの土壤吸着 と, タイヌビエ (Echinochloa oryzicola Vasing.) に 対する土壤処理効果の関係, 及び, それらと土壤の 性質との関係を検討した。低 $\mathrm{pH}$ の土壤で，PSEの 土壤吸着が大きい事が示されたが, 除草効果との相 関は見られなかった。PSEの除草効果は炭素含量の 少ない土壤でより高い傾向が見られた。

キーワード : ピラゾスルフロンエチル, 環境要因, 吸 収部位，ミズガヤツリ 